\title{
STUDIES ON THE CILIATED EPITHELIAL CELLS OF THE MUCOUS MEMBRANE OF THE MAXILLARY SINUS BY PHASE CONTRAST MICROSCOPY
}

By

\section{T. KOHSAKA}

From the Department of Oto-Rhino-Laryngology, Faculty of Medicine, Hirosaki University.

\author{
(Director: Prof. S. Katagiri)
}

With the aid of phase contrast microscope the author studied the ciliated epithelial cells of the mucous membrane obtained from the maxillary sinus at the time of operation.

The results were as follows :

1. It was possible to observe the form of the cells and cilia, basal bodies, nuclei, mitochondria, storage granules, Golgi's apparatus etc. without staining.

2. The ciliary movement was mainly shown in hooked type. its effective stroke, recovery stroke and metachronism were observed distinctly, but in few cases climbing movement was observed.

3. The ciliary movement became gradually inactive and finally ceased, and then nuclear membrane became brilliant and double-contoured with the lapse of time. Further, the cell showed a tendency of swelling and at last the protoplasm and niuclei were destructed, but in few cases contraction of the cells was observed.

4. Studying the effect of various chemicals and durgs upon the ciliated epithelial cells, it was confirmed that fixatives produce distinct changes for living cells. Distilled water showed marked influence on the cells where normal saline did not show any significant change.

\section{位相差顕微鏡による上顎洞粘膜線毛上皮細胞の観察}

\author{
弘部大学医学部耳尊咽喉科教窒（主任：片桐主一教授） \\ 幸坂劫男男
}

舶 言

上颚洞粘膜に関する砳究は古くから行われているが， その多くは固定，包埋，染色等の操作を施したいわば死 んだ細胞についてなされている・しかし細胞学的研究は 生きている細胞について最も自然に近い状態のもとで観 察することが望垔しいと考光られ，今回私は位相差顕微 鏡を灾用して生態時の上顎洞粘膜線毛上皮細胞を観察 し，またその洔間の経過に伴う形態的变化並びに種々の 化学物質及び蘈方に対する反応をも観察したのでこつに 報告する・
研究材料並びに研究方法

研究材料は手術によつて得た上顎洞粘膜片で，粘膜剔 出の際の人工的損傷を可及的少くしかつ麻酔剂の影響を

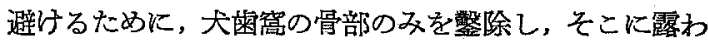
れた粘膜を尖刀でるつて切除した粘募片，及び上顎洞鼻 腔側粘膜あるいは側壁粘膜の一部を骨壁より剔離した 後，剪銙で剪除した粘膜片を用いた・このようにして得 た粘膜片を直ちに人血墏中に投入し，粘膜表面をメスで 軽く蛋爬して載物ガラスに載せ，人血綮で封入し，主と して DLL 及び NDL の位相板を有するレンズで観察 
を行つた．时間の経過に伴ら変化を観察する際に，封入 乵の蒸発を防ぐために被覆がラスの周囲を流動バシフィ ンでるつて封じたばた薬物に対する反応を観祭する場 合，薬液の 1 滴を被覆ガラスの一端に滴下することに上

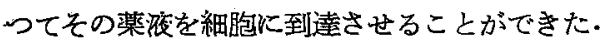

\section{成 績}

A. 対照辟についての観察成續

1）細胞の形態及び内部满造

個々に分離した生活状態にある上罯洞粘脱線毛上没細 胞についてみると，その形態は大部分が円柱状を呈して いるが (第 1 図)，細長なるの(第 2 図) あるいは肥满状 を呈するむのる認められる(第4 図).

䠌毛は細胞の蓄面からほよ゙平行に発生して特り，等質 性湾黑え，これが小皮縁を貫いて細胞体内に入った 所で基底小体に結合している。

基底小体は小皮縁下に一列酒配乙，黑色の球形むし くは紡錐形を呈している(第 1 図).

原形質基質は均等性を呈して质色に見える・核はその 殆んど総てが細胞の基底側に偏しておら，その数は通常 1 個であるが，稀に 2 個存することすある(第 1 図).

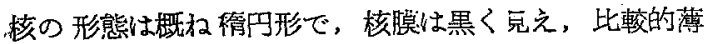
く，一般に平滑であるが甭々その内側面に 2, 3 の突起 が認められる・核質内には 1 万至 2 個の暗灰色高たは黑 色の明瞭な核小体が存在し，またや〉不明瞭な桿代もし くは顆䢂状物質が 不規則に配列しているのが認められ る・ミトコンドリアは暗灰色乃至黑色呈し，㐘状，桿 状及び顆煜状をなして主に基底小体下及び核周囲に存在 する（上频洞粘脱楾毛上皮細胞内ミトコンドリアについ ては別に報告した）。

震々，产の大きさに多少の相違はあるが球形で青色に 輝き黒い輪廓をるつた顆粒が，主汇核より上部沉認めら れることがあるが，その数は多くとも数闻である。

また时折核の上方にあるいは核上極に接し黑色の短桿 状了至琲状物質の不規則な集団が認められることがある (第 2 図).

2) 線毛運動

上硕润粘脱線毛上皮細胞の線毛運動は多くの場合鈎状 運動を示している.この運動に関して分湤した 1 個の細 胞についてみると，線毛運動が激しい洔虫缐毛運動によ つて細胞体自身が一定方向に䛜输しているのが見られる ことがある・かつる線毛運動がや」衰えてくると迴轱運 動は振子様運動比変り，この運動炕伴つて細胞内顆柆等 る動いている様子も見られる・線毛運動が緩やがなり
個々の線毛が識別できるようになると，谷線毛は同時性 の運動を示さず隣接線毛との間に僅かの相のずれるる つて調整された運動を認めることができる。ほた前方へ の固い運動即ち effective stroke と後方へのしなやか な運動即ら recovery stroke む明嘹に認められ，その 運動速度は前者が後者よりも速い，さらに都間が経過し 生活力が弱まるにつれて，線田運動は益々緩慢となり， つい停止するに至るが，この停止火移行する比態に 2 㻎類の樣式がタられる. 即ちその1は各線毛がその協调 性を乱して1本づ〉停止してゆくもので，その2は各線 毛が殆んぞ同時に停止するものである・しかして停止の 状態は前者では多くの場合線毛の配列が乱れて赫り（第 2 図)，後者では殆んぞ平行しておりからや〉 effective stroke 側傾いている(第1図). 多くの場合はか〉る 鈎状運動を示すが，こく一部汇上笔運動を示するのがあ る・即ち個るの線毛は㙝調性を示すことなく下方より 上方に向ら運動で，この運動により赤血冰等は上方に向 つてはね上げられる・このような上舁運動を営む線毛の 停止状態は注丸゙重淔位をとつている。一列に配列した線 毛上皮細胞についてみると，線毛運動に上り線毛列上の 媒質に一定方向の渦流を生じ，赤血球等はこの媒質の流 動によつて移動されてゆくのが見られる（第3 図）．細 胞列上の線毛運動は各細胞の metachronism の連続で

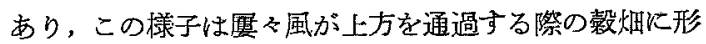
容されているものである.

粘牌剔出後極好て 短暏間内に作彆した標本において も，常に上述したような活發な線毛運動を有する細胞の みが認められるものではなく，そこには線毛軍動が活、留 なもの>他に，微弱なるの，すでに停止しているもの， 線毛が脱落しているもの等が存在し，また細胞列につい てみてる，活潑な線毛運動を有している細胞列中に線毛 連動の微弱なるの，停止しているもの，線毛が脱落して いるもの等が混在し，上述したような定型的 metachronism の墥続状態を示さねことが壓々ある。

3）跨間の経過伴亏細胞の变化

次に陆間の経過に伴ら細胞の変化について観察した。

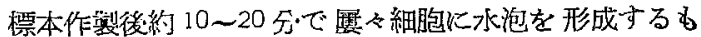

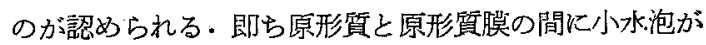
できこれが次第に大きくなり球形を呈し，遂炕細胞

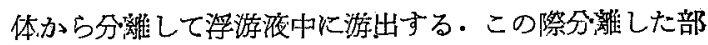
位には欠損部諗められず，またそこから原形質が流出 することるない，そしてこの部位から再び新しい水泡が 形成されることもある・多くの場合はこの所謂局所型で 
あるが，㬴には胞体全体を包むような阙蒙型を生ずるこ ともある・水泡内容は等質で浮游淮上りも僅か心暗く見 え，影折その内容中に小さい黑い顆粒がブラウン様運動 を行つているのが見られることもある・水泡壁は薄く， 2 個の水泡が 接触してもこれらは融合することはない。 この水泡形成はすでに死んたと思われる細胞には認めら れず，また水泡を形成しつ〉ある細胞が死んだと思われ てからはそれ以上の発育形成は認められない。

線毛運動は時間の経過につれて衰え，初め活發な運動 を行つているむのむ多くの場合 1 時間 2 时間以内で運 動の停止をみる. しかし室温で 血獎溶液中に 48 時間浸 婊した粘膜片から作製した標本中に，な線毛運動を続 けている少数の細胞を認めることるある。一般に線毛運 動が活廢なるのは運動持続時間が長く，緩徐なるのほど 持続特間が短い傾向を示している。なお，線毛運動が減 弱した場合あるいは停止直後に新鮮な生理的食塩水で置 換すると，運動は再び活潑になりあるいは再現する（第 4, 5 及び 6 図). 線毛運動停止後さらに時間が 経過する と黑々線毛の脱落をきたす・しかしこの脱落までの所要 時間は一定して扣らず，剔出粘脱によつてかなりの相違 が認められ，標本作站後約 1 時間で標本中の殆んど総て の細胞の線毛が完全に脱洛し去り，脱落線毛か浮游液中 に充満することもあるが，24㭙間以上経過してもなお 眖落をみない細胞を認めることもある(第9図).

線毛運動停止後ますなく核膜は不規則厚くなり，核 の周因が輝いて所謂 double contour を示すようにな る・時間の経過に伴つて胞体は次第に膨化しはじめ，核 るや>膨大し，核营の厚さは幾分减ずる・さらに時間が 経過すると胞体は益々膨大し，ついには原形質膜が破れ るに至る・原形質内ミトコンドリアは顆粒状になり膨大 の傾向它示す（第7，8 及び9図). しかし少数の線毛上 皮細胞は膨化の過程を迎らず，む乙ろ胞体，核等に縮小 の傾向を示ず。

\section{B. 諸種化学物及び薬物の影響について}

最後に穗々の化学物質及び薬物の線毛上皮細胞に及注 寸影響について観察した。

1) $10 \%>\pi ル \vee リ ン$

薬物が細胞に達してから棌ら゙0秒以内に線毛運動は あたかも苦悶するような状態で停止する・胞体及び核は

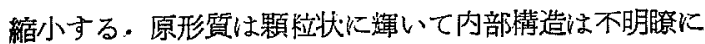
なり，核膜はや小厚く不規則となり，粒いて double contourを示す・核質は雪んだようになり，核内構造も 煇さを帯びてくる(第12 図)。
2) $70 \%$ エトルアルニール

アルコールが細胸に達してから数秒で線毛運動は停止 する. 約 1 分後胞体及び核は軽度に縮小し，約 2 分後 にはその縮小はさらに著明となり，核膜は軽度に肥厚し て不規則となり，甚だしい時は鋸荬状を呈することもあ る・原形質及び核内構造は幾分煇きを帯び，その構造に 明膫を欠くものもある(第 13，14 及び 15 図).

3） $3 \%$ 重クロム酸放

線毛運動は薬液到達後大体 1 分以内に停止する・胞体 及び核は軽度に緶小するが，10\%フォルマッン，70\%万 ルュール程著明ではない．原形質は顆粒状を呈して 輝 き，核臊楎いて double contour を示し，核質は明 るく見光，その中に厴々黒い不規則に配列した顆粒状物 質の集団が認められる(第 16 図).
4) 醋
酸

$5 \%$ 溶液は楾毛運動を瞬時に停止させる・数秒内に線 毛の形，配列が乱れ，盷体及び 核は縮小乙，原形質满 造は顆粒状を呈してや」不明瞭になり，核膜は不規則に かつ軽度に厚くなり鮮明に現われるが，核内は輝いて内 部構造は不明膫になる・次の瞬間，胞体及び核は急速度 で澎大し，原形質は薄く霞んだようになりその構造は全 く不明になるが，ひとり核膜のみは膨大のため厚さを や上琙ずるがな物黑く明らかに認められる（第 18,19 及 び20 図). $0.5 \%$ 溶液では作用徭 1 分〜2 分で線毛運動は 停止し，胞体は僅かに縮小を示し，原形質内は顆粒比に 輝いて内部门溝造は明瞭を欠く・核膜は厚くなりかつ不规 則に縮小して double contour を示す。構内棈造は青 昧を帯びて辉いてくる(第 17 図).

5） $1 \%$ 苛性力

薬液作用瞬間に線毛運動は停止し，引緦いて胞体及び 核は急激江膨化をきたし，原形質膜及び核膜が溶解して 細胞内構造物が浮游夜中に散乱するが，まもなくこれ等 も溶解消失する・たら゙特殊顆粒のみが变化なく残つてい る(第 21 図).

6) 蒸 溜 水

蒸溜水が細胞に作用してから大泍 5 分〜10 分で線毛 運動は停止する・胞体は膨化し，原形質内ミトニンドリ アも膨大し永形となるが特殊顆粒には著变を認めない。 核は比較的急速に膨大し，核膜は薄くなり，核内は霞ん でその内部溝造は不明瞭となる・また水泡の形成は促進 される(第 10 及び 11 図).

7) 生理的食馧水

生理的食塩水で置換してもその線毛運動に变化なく， 


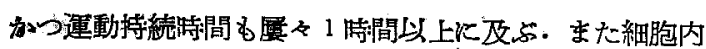
部構造にる大した变化は認められない。

8) 塩酸コカイン

10\%溶液では線毛運動は大体２２分以内で停止する・薬 液作用後ますなく胞体は軽度に縮小し，原形質はや〉輝 きを带びて内部搆造が不明㬌になり，校膜は不規則に幾 分厚さを堌し double contour を示するのもある・核 内は明るくなり顆粒状構造が輝いている５\%溶液では 線毛邁動は 5 分〜7 分で停止し，胞体の縮小並びに内部 構造の変化は $10 \%$ 溶液とほ心同じである.2\%溶液で

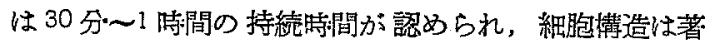
变を示さない。

9) 塩化アドレナシン

$0.1 \%$ 溶液を作用させて子線毛運動は直らに停止せず， 5 分〜7 分の運動持続をみる・蝶液作用後まるなく胞体 は軽度に縮小し，原形質及び核内構造はや小輝きを帯び るようになる・0.01\%溶液では線毛運動は㷴々 30 分以 上に及び, 細胞構造にも大した変化は認められない.

10) $5 \%$ ロタルゴール

5\%ブロダル゙ールは 5 分〜10 分で線毛運動を停止さ せる・線毛運動停止後原形質はや」輝きを带びるがミト コンドりア等は明蹽に認められる・核膜は多少不規則に 愿くなり核質も僅か儿辢くが，核小体は明䐲である。

11) 水性ペニシリン

水性ペニシリン10万単位を10cc の生理的食塩水で 溶解したものでは, 線毛運動は30 分以上持続し, 原形 質及び核搆造にも变化は認められない。

12) $0.05 \%$ プリビ

0.05\%ブリビナを作用させた場合，その線毛運動持:続 特間は短かく忹ぶ 2 分以内で停止可る・最初核質が霞む が次に核内構造が楎いてくる・胞体及び核は次第に縮小 し，原形質も顆粒状に䍇き，核膜は不規則に厚くなり， double contour を示してくる.

13) ナーヘ

薬液作用後にも線毛運動に格別の変化が認められず， その持続持間は 30 分以上である・原形質及び核内構造 にも著変は認められない。

\section{繶括並びに考按}

従来より行われてきた上顎洞粘膜の細胞学的研索は主 に固定染色䅺本についてなされてきたが，からる研究方 法によつては線毛の運動状態を観察することができず， またすでに Proetz (1946) は線毛上皮細胞は固定及び

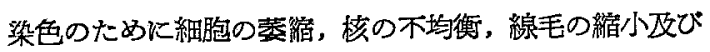

混乱をさたを指摘し，森 (1936)慓本作製に便用する 固定液の性状により，あるいは染色法の言異，升色の程 度によつて異つた微細構造を示すと述べているよらに， 細胞棈造は固定, 包埋, 薄切, 染色等の操作中に物理化 学的影響による変化を免れ得す，従つてその細胞学的研 究はからる操作を加えない生きている細胞について行わ れることが最子理想的であると考えられ，さらに固定染 色標本では特殊染色法によらなければ認めることができ なかつた細胞内部棈造をも同一標本において見ることが できるとい5点から，上顎洞粘膜線毛上皮細胞の観察に 位相差顕微鏡を応用したるのである。

本研究に岕いては標本作㱔漈して可及的線毛上皮細 胞に人工的影響を加えないようにすることが必要である と考えられる.この人工的影響として第 1 に手術時の機 械的刺㦸並びに局所麻酔剂の影響，第 2 にメスによる掻 爬という機㑘的刺战を考慮に入れなければならない，第 1 の場合については，犬雪䆚の骨部のみを除去して，そ こに露われた粘膜を無麻酔のもとで牙除することにより この刺践を避け得るものと考え，かくして得た粘膜片を

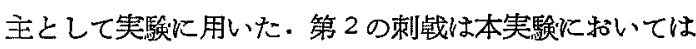
不可避であつたが，戸谷（1956）は同様の操作を行い。 細胞分灕の操作によつては細胞の形態学的変化は認めら れなかつたと述べている.しかしとこに㭗爬という操作 が行われる上上は当然多少の刺钺が加わり, 篦密には全 く人工的影響は無いとは云い得ないと思われるが，その 影響範围は比較的少く，本笑験には大した支障をきたさ ないものと考えられる。

位相差顕微鏡による上顎洞粘膜線毛上皮細胞の観察は すでに 1955 年渡辺によつて 行われているが，その内部 㩐造に関しては余り詳紬に報告されていないこれは生 理的食塩水あるいはリンゲル氏液を封入方とし，また 3/4 波長膜位相板を使用したためにその内部教造が明蹽 に観察できなかつたのではないかと思われる・生理的食 塧水あるいはリンゲル氏液はその屈折率が低く，従つて 䅺本との間の屈折率の䓂が大き，このよ5な細胞の観 察には封入剂として余り好ましくないとされて扣り，水 平 (1952) が強調するように, 使用する動物の血獎ある いは腹水を用いるのが最適であるように思われる・私す 以前に生理的食盘水を封入斉とし，3/4波長膜位相板を 使用して観察を行つてみたが，像は嘾き，像の周团に halo を生じて位相差の像は坟され，また像の contrast が逆転したりしてその内部满造の観察に明睹を欠くるの

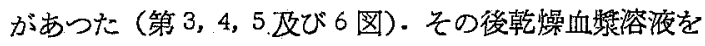


封入剂とし，また従来用いていた $3 / 4$ 波長膜位相板を有 するレンズを土 $1 / 4$ 波長膜位相板を有する DLL ある いは NDL のレンズに替觉ることによつて比較的明膫 に内部構造を顴察することができた。すた 1956 年戸谷 は普通顕微鏡によつて新僬標本の上頍洞粘膜線毛細胞を 観察し，従来の顕微鏡をるつてしても細胞の形態並びに その構造が簡単に究明できると迹べ, 絓胞の形態及び線 毛運動に関して詳細に報告しているが，その内部構造に 関しては全く論じていないようである.実際，普通光学 顕微鏡による新鮮標本の観察に执いて, 屈折率の美が大 きい線毛や核等の存在はある程度認められるとしてる， 屈折率の善が小さい細胞内微細構造の観察は到底不可能 なものと思われる。

上彭洞粘莫線毛上皮細胞の形態は一般に円柱状である といわれて括り，私の観察に招いても艺の大部分は円柱 状であつたが，一部のものは肥満状あるいは細長い形を 呈していた・戸谷は形態的にこれらを4型に分類してい るが，白川 (1957) はこれら形態的変化は疾病の経過々 程に括いて起つたるのとみなしている・線毛運動の停止 あるいは線毛の脱落等を示しているるのは膺々細胞体の 膨化をきたして形態的に肥満状を呈しているすのがあ り，か」る細胞は病的变化に上るものと云い得ると思う が、活潑な線毛運動を行つている細胞にる肥满状あるい は細長な形態を呈しているものもありこの場合，分離 した細胞についての観察からはこれが正常状態下にある るのか，あるいは病的過程に拈けるるのかは一概灯断定 することはできないが，活潑な線毛運動を示す事夷を見 れば，正常機能を有する線毛上皮細胞にるこのような形 態を呈するものもあるるのと推測される. Sternberg は線毛細胞は杯状細胞と同一のものであり，そのような 形態的変化は機能的要求に応ずるるのであると云い， Messerklinger む杯状細胞は病的状態に物いて線毛細 胞から移行すると述へで扣り，また白川の研究によつて あかつる事奏を罢書きするような結果が出ている・しか し私の位相差顕微鏡による観察からはこのような移行状 態を見出すことは困難であつた。

線毛は1683 年 Anton de Heide によつて初めて観 察されたが，その機能面より1891年 Schäfer は線毛 は原形質基質で充され，弾力性膜で包被されていると仮 定し，1911 年 Heidenhein は線毛は中心性芯を有して いると考觉た。まな組織学的に Nussbaum (1887), Loeffer (1889), Fischer (1894), Schuberg (1905), Erhard (1910) 等は線毛内に縦軸小線維を観察してお
り, Dellinger (1909), .Korschikov (1923), Grave 及び Schmitt (1923) 等は線毛は多くの組線維から成 つていると報告している.1954 年 Fawcett は電子顕 微錇下に線毛の中心に 2 本の線維があり, その周囲に9 対の線維が縦走していることを観察し，上述の Nussbaum 等の報告した構造が 普通の 光電顕微鏡によつて 見出されたことは理解し難く，これは凝固した蛋白質並 びに染色液によるるのではないかと解釈している，位相 差顕微鏡による私の観察では線毛は等質に見え，Schäfer の管腟並びに弾力性膜, Heidenhein の中心性芯, Nussbaum 等の縱走線維等は認め得なからた。

基底小体む Fawcett 等の電子顕微鏡的観察では中心 に原形質性の芯を封じ，周囲に好吕ミウム酸の密な䩗 を有し，その形態も非対称的に見出されているが，私の 観察では従来述べられているように球形あるいは紡錐形 の等質性小体として小皮緑下に一列に配列し, 線毛と連 結して認められた。

原形質基質は等質性で灰色涀えること，核膜は比較 的薄く，その外側は平滑であるが内側に屡々 2,3 の突 起が認められ，核内に黑色の明瞭な核小体及び不明瞭な 桿状むしくは顆粒状物質が不規則に配列している粗なる ロマチン網工が存在すること，原形質内暗灰色ないし 黒色のミトニンドリア及び青色を帯びて輝き明瞭な黑い 輪廓をるつた顆粒即ち特秼顆粒が存在し，後者は線毛上 皮細胞に执いては比較的数が 少いこと等は Zollinger の位相差顕微镜による種々の細胞に和ける細胞学的研究 の所見と概小一致していた. Zollinger は氏の研究に拉 いてゴルジ装置は証明できなかつたと記載しているが， 私は線毛上皮細胞において時折核の上方にあるいは核上 極淁して黑色の短桿状あるいは球状物質の集団を認め た。これはミトコンドリア及び特殊顆粒とは外観上明ら かに異なるすので，単にこの観察から断定することは困 難であるが，私はその形態並びに位置的閶係からゴルジ 装置ではないかと推察した。また線毛上皮細胞核が直接 分裂を行らことはすでに森等によつて認められている が，私も直接分裂に上ると思われる2 個の核を有する細 胞を認めた。

Valentin によれば線毛運動型は振子状運動，鈎状運 動，漏斗状運動及び 波動状運動の 4 型に 分類されてい る.清水 (1955) は悬粘膜線毛は鈎状運動に属すと述べ, 戸谷は上顎洞粘㬴線毛細胞の運動を波状運動型，火焰状 運動型及び中心部集合状運動型の 3 型に分類している. 私の観察ではその大部分が Valentin のいら鈎状運動を 
示しているが,ごく少数のものに上昇運動を示するのが 礛められた・鈎状運動は戸谷のいら波状運助型に，上昇 運動はその火焰状運動型るしくは中心部集合状運動型に 相当するもの之考克られるが，後者の運動比態を戸谷の 如く火焰状と中心部集合状とに明確に区別することは困 難なように思われた。

鈎状運動には前方に向う effective stroke と旧位に 復す recovery stroke とがあり，前者は固く線毛の曲 りが尖端から根本に向い, 後者は柔軟で線毛の曲りが根 本から尖端に向つて敊り，その速度は前者が後耆よりる 速い.また個々の線毛は同位相の邁動を示すことなく绦 接線毛との間僅かつつの位相のずれをるつて調整され た運動を示している・この運動状態か所謂 metachronism として知られているものである.これ等の所見は Proetz, Tremble, 瀨尾, 清水等がすでに記載してい るそれと全く一致している・しかしこの線毛運動及び metachronism はいかなる 機転によつて営まれている かは今日なお明らがされていない.Schäfer の線毛は 弾方性膜で包被された管腔で，線毛運動は原形質基質の リズミカルな出入によつて起るという仮説や, Heidenhein の線毛は中心性芯を有し，その収繀他緩によつ て線毛運動が起るといら学説はすでに唇定され，近年 Fawcett 媳び Porter はその電子顕微鏡的研究より， このような運動には基瓦小体が密接な関倸を有するらし いと推論している.

活潑な線毛運動も時間の経過につれて炊第に緩慢とな りつル停止するに至るが，その停止に移行する状態に つい, 渡辺は各楾毛の足並か乱れて1本づ運動停 止してゆくと述べて括り，戸谷はその動熊的推移型を 2 型に 分類し，I 型は衰䫋期には運動停止前 30 秒〜2 分 で急に速度が鈍り次第に衰えるが如く停止するもので， II 型は運動停止 20 分〜30 分前より 不変期と明確な限界 を示すことなく徐々に衰觉るが如く停止期に移行するる のであるとし，また停止状態る全線毛が一定方向に向つ て停止する場合と，線毛が不規則に各方向に向う場合と を認めている．清水はや〉有效打側に傾いて停止すると 述へているが, 私の観察では戸谷の所見とほら゙一致して いた・たが戸谷は線毛運動に上万に向う運動を認めてい るにもか小わらずその停止への移行状態及び停止状態に つては論じていないよらであるが, 私の観察ではこの ような運動を示するのつ多くはその協調性が乱れだを〉 停止状態に移行し，停止状態は大体垂直位をとつてい た.
線毛運動により線毛列上の媒質に一定方向の瀜流を生 じ，異物等がこの媒質の流動化よつて運搬される状態は すでに渡辺, 白川等によつて認められているるのである が，私るこのような状熊を観察し得た。しかして媒質流 動の方向は recovery stroke の方向に向らものである. 異物等の移動の大部分は線毛自身によるるのではなく媒 質の流動によるすので，生体内に括いてもその線毛運動 により線毛列上の粘液痹に流動を生じ，これによつて 異物等が運搬されるであうらということは想像に難く ない.

慢性炎症粘膜に和ける線毛運動について，Proetz は その運動は殆んど損われることがないと云い，小倉

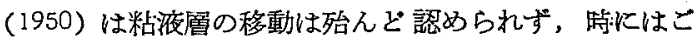
く微小な移動を認めるが，これは線毛運動が微弱である かあるい性不協調であるためであろうと推論し，戸谷は 指摽の不動は広範囲に亘る線毛の欠落によると考兄，線 毛運動自体の微弱は認められなかつたと述べている・私 の観察した標本においては線毛運勒の活潑なるの, 微弱 なるの，停止しているすの並び線毛が脱落しているも の等が混在し，そこには手術及び搔爬の際の機械的影響 が加わるにしち, 線毛運動の微弱ない儿停止, 線毛脱落 等の総てが機械的刺㦸によるものとは考穴られず, 生体

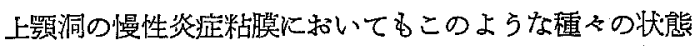
の線毛上皮細胞が存在しているものと思われ，Proetz のように線毛運動は損われていないとは断言し難く，小 倉の観察した粘夜層の微小な移動は微弱な線毛運動を有 する細胞群上飞発現し，また粘液層あるいは指標の不動 は単に線毛欠落によるのみならず, 䠌毛運動が停止して いる細胞群の存在によつても㟟起するものと考它られ る・また Hilding, Proetz 等はその粘液層の流れは非 直線的でありかつ同速度でないと報告しているが，これ は線毛運動型並びにその速度の相違及び線毛運動停止 細胞, 線毛脱落細胞等の 混在に由来するるのと考克ら れる。

なおっ，基磪膜より分離した 1 個の線毛上皮細胞で，線 毛運動が激しい時气の運動によつて細胞自体が一定方 向に迴転しているのが見られることがあるが，これは標 本作製の際に被覆がラスに加える圧が少い場合，即ち載 物ガラスと被覆がラスとの間の間隐が大きい場合に庥ふ 見られこのような標本は運動状態を観察するには適し ているが，細胞内部搆造を観察するには不適当で，この 場合にはるら少し被覆がラスに压を加えることによつて より明睹に内部構造を観察することがでさるといらこと 
を知つた。

線毛上皮細胞の水泡形成はすでに渡辺によつて観察さ れて扣りまたZollinger，水平む種々の細胞に扮ける 水泡形成について記載しているが，私の観察に特ける所 見もそれ等と殆えと゚一致していた．Zollinger はこの水 泡形成は大低の細胞に認められるもので，浮游液に直接 飞接触している遊離面及び細胞の生存能力の存在, 並び 飞硬固な細胞外皮の欠除といら3 因子の存在のもとに発 生し，水泡内容は原形質の一部でゾルの状態にあり，水 泡壁は細胞膜之同一物らしく，水泡の接触によつてる融 合しないのは表面張炕よるものと考允られ，しかして この水泡形成は生きている細胞の活發な活動状態である といつている・これに対して水平は，細胞が直接に浮游 液に接触するために起る一種の細胞の異常状態で，死一 の歩みの第一歩とみるべきではないかと推論している. 私の観察では水泡形成を営みながらも活潑な線毛運動を 行つている細胞も認められたが，一般に水泡を形成して いる細胞の線毛運動は緩徐で間むなく停止に移行するこ とが多かつた。

剔出粘膜の線毛運動持続時間に関する戸谷の奏験によ れば, $8^{\circ} \mathrm{C}$ 前後の生理的食塩水あるいはりンゲル氏液中 で最低 48 時間, 最高 120 時間の運動持続を認めている が，私の観察では室温の血漿溶液中で 48 㭙間後な括線 毛運動を持続している少数の細胞を認め得たが，72時 閒後には全く認められなかつた。また線毛運動停止直後 新鮮な生理的食塩水を注加することによつて線毛運動が 回復することを認めたが，この事は Zollinger む見て 特り，また渡辺る稀薄ア几コール及び加温に上り線毛運 動か再現することを観察している。この事㿤から線毛運 動の停止のみをるつて直ちに細胞の死と判定することは 早計と思かれる・渡辺は細胞の死後 6 時間〜12 時間で 線毛は完全㜔落すると報告しているが，私の観察では 剔出粘膜によつてかなりの相違が認められ，標本作㢣後 約 1 時間で完全に脱落することもあり，また 24 時間上 上経過してあな和脱落をみないこともあった。

Lewis 及び McCoy は核の屈折性の増加及び明らか な核膜の出現をすつて 細胞死の定型的徽候である之考 え，Zollinger は動物実験によつて䡣いた核を有する細 胞は死隇していることを実証し，線毛上皮細胞において

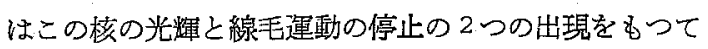
細胞の死を判定することができると述べて括り，水平も Zollinger の見解を全面的炕認めている. 私の観察にお いても線毛運動が停止しかつ核の輝きを示している線毛
上皮細胞は新鮮な生理的食塩水の置換等の操作によつて る，むはや線毛運動の回復は認められなかつた。

線毛運動はその活動が活潑なるのは運動持続時間も長 いが，微弱なるのは比較的短時間内に停止するというこ とを観察した・從つて微弱な線毛運動を有している細胞 飞薬物を作用させた場合，その運動持続特間が薬物の影 響によつて短縮されたるのかあるいは薬物の影響を蒙ら なくとも自然矤猎間内に停止したるのかを区別するこ とは不可能である：よつて楽物の線毛運動に及ばす影響 を観察する場合は涺潑な線毛運動を行つている細胞を対 象とした・またこの観察の際 Zollinger は薬液に少量 の中性紅を加えて拉くことにより藥液が細胞に達する瞬 間を判定できると記載しているが，この方添を追試して みた結果は着色が薄くその到達瞬間を明腹に判定するこ そは困難であつた・戸谷は薬液に生理的食監水で溶酸し た $2 \%$ マーキュロクロームを0.01\%の割合に混入し， この赤染液が線毛に接触した瞬間をみているが，この方 法も位相差鏡下では不明䐲であつた・被覆がラスの一端 に灙い色素液を滴下し顕微鏡下に観察していると，色素 液は速かに封入液中に浸入し，比較的辺緑部の細胞には 大体 2 秒 3 秒で到達する.よつて私はこの事を念頭に 入れかつ添加色素によつて位相差像が壊されることを考 慮し，薬液には色素を加えずに観察した。

渡辺は $5 \%$ 重クロム酸カリ及び $10 \%$ オルマリンを 䠌毛細胞に作用させ，最初細胞体の収縮之線毛運動の減 衰, 数分後に原形質の透明感の増加々線毛運動の停止を 認めまた細胞体の変形を示すことがあると述べてい る.Zollinger は，10\%フォルマリンを生きている細 胞に作用された場合は数秒徯に核は霞んで等質に見え僅 かに萎縮をきたし，細胞は輝き，核小体及びクロマチン 粯工は腪き青みがかつつてき，また核腽は不規則に厚く なり輝いて double contour を示す. しかして70\% $95 \%$ ルュールす同様の变化を起すと記載しており，ま た水严む固定液による作用を種々の細胞で調へ Zollinger と全く同じ所見を得たといつている.さらにZollingerによれば3\%重クロム酸カリは核に特有の変化を きたし，作用後 2 秒〜3 秒で核膜は厚くなるが輝くこと はなく、クロマチンは網状構造を失い核質中に不規則な 暗い点として現われ，核小体は非常に明瞭に認められ る・しかし最後には核は萎縮し精いてくるのでフォルマ リン、アルロール等で処理したものと区別ができなくな るという・私も一般個定液として用いられている10\% フォルマリン，70\%アルニール 及び $3 \%$ 重クロム酸カ 
ソについてその線毛上皮細胞に及ぼす影響を観察し，こ れ等固定液は線毛運動を大体 1 分以内で停止させ, 强烈 な影響力をるつていることを知つた・また細胞体に対し てもこの3者はほら類似した变化を惹き起した・即ち原 形貿は縮小乙その内部满造は顆粒状に輝いて不明瞭に なり，核も縮小し核膜は不規則に厚くなりかつ糐いて double contour を示し，核内構造む数きを帯びて明瞭 さを欠いた・たづ原形質及び核の縮小程度は70\%アル ニールに特いて最も顕著であり $3 \%$ 重クロム酸っリでは 比較的軽度であつたが，内部構造の光䊅は後者において 最も著明であつた・止上の所見は Zollinger のそれと 類似している点が多かつた・しかし $3 \%$ 重タロム酸かり において Zollinger の所謂中間段階ともいうべき变化 は認められなかつた・要するにこれ等固定液は細胞蕉:白

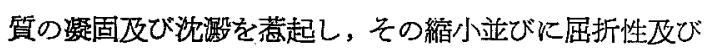
昨膫度を堌するのと考えられる・彷来, 細胞学的研究は 生きている状態においてなされるのが理想とされている にむかっわらず，その生態観察が不充分なために固定液 により細胞に変化を招来することを熱知しつつも止むを 得ず固定操作を施し，固定標本所見を基碟として生熊時: の榡造並びに機能を推論していた状態である.本実験に おいてはその固定液が生能㭙の細胞に及ばす影響につい て観察したものであるが，細胞構造に著明な変化をき たし，生態時とは大分異つた所見を呈することを知り 得た。

$5 \%$ 醋酸を細胞に作用させた場合，渡讱の実験ではコ オルマリン等とほら゙類似の現象を示すと云い，Zollinger b原形質は収縮せず゙，ミトコンドリアは著明に膨 大するが，その他はフォルマリンと同じ態度をとると述 ベている・しかし私の実験では両者とはかなり暴つた所 見を呈し，線毛の運動は瞬時に停止してその形及び配列 か活れ，細胞は一見縮小像を示すが，ついで急速に膨大 し原形質構造は薄くなつて全く不明睧になり，単に核の みが黒く現われてその存在を示している状態であつた。 しかして $0.5 \%$ 醋酸による変化がむしろ渡迅, Zollinger の報告に類似していた。

$1 \%$ 苛性カリによる変化は渡辺の観祭とほぶ一致して いたが，特殊顆粒のみが溶解されずに不変のま入視野に 散在しているのが印象的であつた。

蒸溜水を作用させた場合の線毛運動持:続時間につい て，佐伯は 15 分，戸谷は 2 分〜7分，Zollinger は12 分以上であると報告して拉り，私の場合は大体 5 分〜10 分であつた・これに比べて生理的食篮水の場合はその掊
絸咕間が遥が長く，“产は 55 分〜88 分の運動持続を

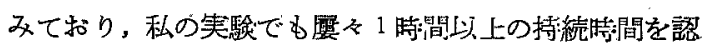
めた。はた蒸溜水中では原形資の膨化，ミトコンドリア の膨大，核の霞型变化等を惹き起したが，生理的食塩水 中では細胞構造に大した変化は認められなかつた・か】

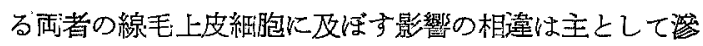
透生の差に因るものと考えられ，従つて臨床上薬威を溶

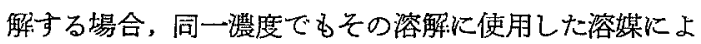
つて線毛上皮細胞に及ぼす影饗にる当然差異をきたする のと考えられ，溶媒としてはでき得る限り生理的食監水 を用いることが望ましいと考えられる・また蒸溜水中で 水泡形成が促進されることはすでに水平，渡辺，Zolli“ nger 等によつて認められているが，これる原形質と媒 質との間の唀压の大さな奎によるものであろらといわ れている.

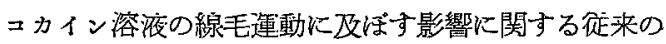
報告をみると，10\%溶液では戸谷，Proetzは2 分以内， 白川性 1 分, 佐伯は 30 分内外で停止，5\%溶液では戸 谷は9 分〜5分，Proetzは1分〜3分で停止し，また2 \%溶液ではP Proetz は砝んど影響がないと述べている

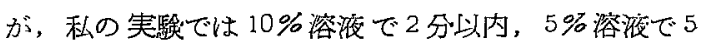
分〜7 分，2\%溶液では大体30 分〜1間の運動持続特 間が認められ，その成結は上述の諸代のそれとほざ一致 していた。また $10 \%$ 及び $5 \%$ 溶液では蒋液作用後まむ なく胞体の軽度縮小，原形質及び核内構造の輝きをみる ものもあり，その線毛運動持続时間の短縮とから，この 鼬度のコカイン溶液は線毛上皮細胞に対してかなりの影 㗽力を有するすのと考它られる。

塩化アドレナリンについて0.1\%溶洨では戸谷, Proetz は直ちに停止，佐伯は1 万力内外で停止するというの に対して，白川，渡辺は減弱するが停止はしないと述 ベその報告にはかなりの相遙が認められた・私の夷験 では直らに停止することはないが，その多くは5 万゚〜7 分で停止した。また白川，渡辺は0.1\%アドレナリンの 作用により細胞体に著明な収緧が起ると記載している が，私の場合にはさほど著明な緶小は認められず，また 原形臂及び核内構造に軽度の輝きを率びてくるが，その 構造に明膫を欠くほどのむのでなかつた。0.01\%尔溶液で はProetzは 2 時间以上の運動持続をみているが, 戸谷 は5分ー3分で停止するといつている・私の結框では 怔々 30 分以上の運動持:続を認め，細胞構造にも大した 変化はみられず，従つて0.01\%溶液の細胞に及ぼす影 響は此軑的弱いるのと考えられる。 
プロタルー゙ールを作用さ妨た場合について戸谷は $2 \%$ 溶液で 1 分以内， $1 \%$ 溶液で 9 分〜15 分， $0.5 \%$ 溶液で 10分〜24 兮で，また佐伯は 2\%溶液で平均 5 分，10\% 溶液では平均 55 秒で線毛運動が停止すると述べている

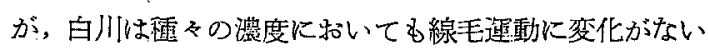
といつている・私の実倹では 5\%溶液で5 万ナ〜10 分の 運動持続間を認め, 細胞構造において子核膜の柽度不

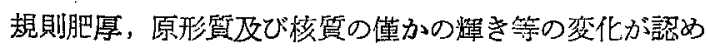
られたが，その内部構造は比較的明瞭で，プロタルゴー ての細胞に及ばす影響は余り強烈でないと思われる。

戸谷の研究によれば水性ぺニションはその濃度いかん にかつわらず正常に近い、線毛運動持続㭙間を示すといわ れているが，私の実䮈に势いても10万単位を10。の 生理的食程水に溶解した溶液では30 分以上の運動持続 时間を諗めから細胞内部構造にも变化を示さす゚，その細 胞に更ばす影響が少いことを和つた。

最近鼻閉塞に対する局所血管収維成として使用されて いる0.05\%プロビナ及びァドナの線毛上皮細胞に及ぼ す影響について頫察を行つた・ブリビナは線毛運動持続 时間を短縮し，また細胞内部檴造にも著明な変化を起し たのに対し、アドオは線毛運動に障碍を与えずかつ細胞 内部溝造にも著変が諗められなかつた・この結果より血 管收總作用は別としてその細胞に及ぼす影響は前者が後 者よりも強いのではないかと推测される。

1934 年 Lierle 改び Moore が 上気道粘膜線毛㞄動 に文ぼす薬物の影算について報告して以来ここれに関す る報告は多くの研究者によつてなされており，最近では Proetz (1946)，佐伯 (1951), 清水 (1955), 戸谷 (1956) 等の報告が双らる・しかしその多くは動物あるいは人 間の粘膜上皮列を対象としているために詳細な観察は困 難なものと思われ，この点から戸谷は個をに分㒕した線 毛上皮細胞についてその運動持:綕声間並びに線毛運動停 止に至る過程の動態的推移を観察し，これによつて㭼物 の毒性を推測することが可能であるといつている.しか 乙その細胞に及ぼす影響については単に線毛運動の変化 のみならず細胞内部櫣造に及ぼす変化をる併せて論ずる のが妥当と教充られ，私はこの両者について観察を行つ たが，線毛運動捎;続時;間の短縮と絓胞内部構造の変化の 强さは平行䦎係にあることを知つた。

\section{結論}

位相差顕微鏡により上顎洞粘脱線毛上皮細胞を観察 し，次の所見を得た。

1）線毛上皮細胞の形態並びに線毛，基底小体，核，
ミコンドリア，特殊顆妵，コルジ装置等を無染色のま 〉観察することができた・

2）線毛運動は主に 鈎状運動を示し，その effec:ive stroke と recovery stroke 並びに metachronism 明瞭に認められたが，一部に上算運動を示するのがあ つた.

3）生熊時:の細胞に綮く水泡形成が認められた，時間 の経過に伴い線毛運動は減弱加停止に移行し, 停止洛 核が輝いて所謂 double contour を示してくる.さら に胞体は膨化の傾向を巡り，ついは原形質及び核が破

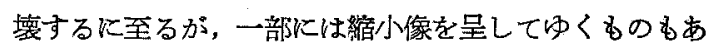
つた・

4）種々の化学物質及び蒋物の線毛上皮細胞に及ぼす 影響について観察し，固定液は生態時の細胞に著明な变 化を蕉き起すこと並びに蒸溜水は生理的食笽水に比へて 細胞に及ばす影響が影著であることを知つた。

\section{主 要 文 献}

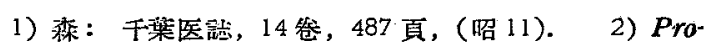
etz: Applied physiology of the nose. Saint Louis. (1946). 3) Zollinger: Am. Jour. Pathol. Vo'.

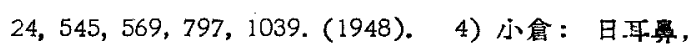
53 聟, 1 頁, (炤 25). 5) Tremble: Arch. Otolaryngol. Vol. 51, 205, (1950). 6) 合时, 藤北：生理 学講座, 1 癸, (诏 25). 7) 稻垣：位相差顕徽鏡の 臨床的応用, (炤 26). 8) 佐伯: 広岛医学, 4 臰, 38 頁, 543 頁，(炤 26). 5 参, 285 頁，(㗁 27).9）水平： 位相虎顕微鏡とその応用，(沿 27）。10）升上：耳喉 科，24卷，547面，(昭 27). 11）瀨尾：生理学唡连, 2 卷, (骝 27). 12) Tremble: Laryngoscope. Vol. 63, 619, (1953). 13) Fawcett: Laryngoscope. Vol. 64, 557, (1954). 14) Fawcett and Porter: Jour. Morphol. Vol. 94, 221, (1954). 15) 波辺：

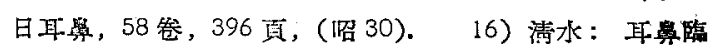

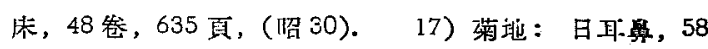

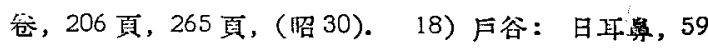

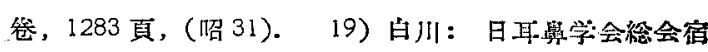
題報告，(炤 32 ).

\section{附 図 説 明}

第1図細胞体厂四状を呈し，2個の核が認められる. 線毛はぼ平行に発生して基底小体と結合している。

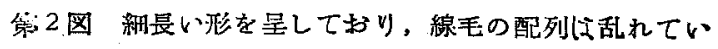
る・核の上方にゴルジ裝置と思われる黑い顆粒状物賀の 


\section{箱団が铝められる。}

第3 图活潑な線毛運動を有する上皮細胞列・線毛列上

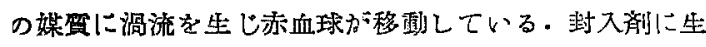
理的食塩水を用い，3/4 波長脂位相板を有するDM で

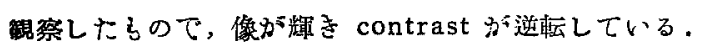
第4図 肥满状を是する䋚胞で活激な線毛運動を行つて いる.

第 5 図第 4 図に゙示したのと同じ啝胞で，約 40 万経過

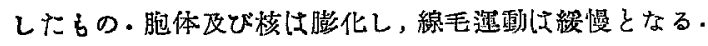
第6図 第 5 図のるのに新解な生珪时食程水を扣えたと

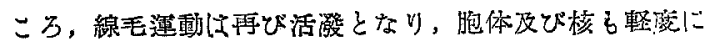

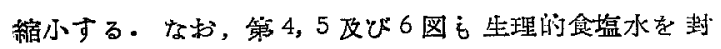
入用とし，3/4 波長膜位相板を有するDMで観祭した るので，その止部構造け不明嘹でかる。

第7図 線毛運動停止後約 30 分経過したるので，核牌 は不規則に厚くなり，周囲が輝いて double contour を示す.

第8図 第7図と同し沺胞で18 時間経過したるの・胞

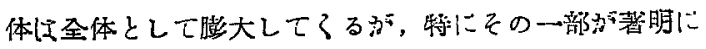

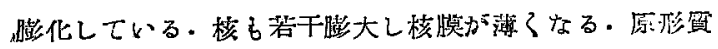
內ミトニンドリアる顆粒状になりかつ㜆大している。 第9図第7図と同じ細胞て 36 時間経過したるの・胞 体及び核は益々膨化しているが，線毛はなお保たれてい 3.

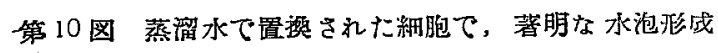
加諗的られる。

第11図 蒸留水で置換された沺胞で，核の霞型を示す。 原形筫丙ミトニンドリアは颜大している。

第12図 10\%フォルマリンを作用させた細胞で，胞市 及び核は軽度に縮小し，原形筫丙檴造に顆粒状に盶いて

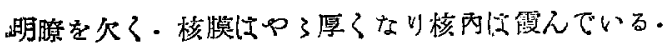

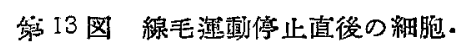

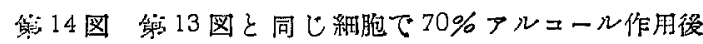
䄪1分経過したもの・胞体及び核が軽度に縮小する・ 筙 15 図 第13 図上同じ細胞でアルュール作用後約 2 分

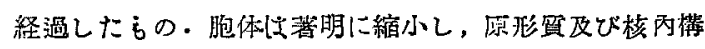

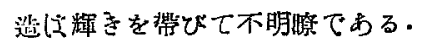

篗16図3\%重クロム酸カリを作用させた沺胞・原

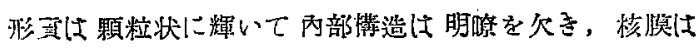

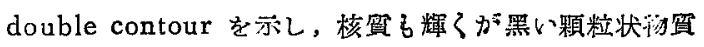
の不規則な集団がみられる。

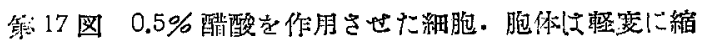

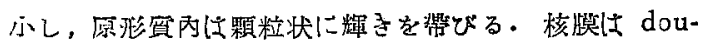
ble contour を示し, 核队構造し輝いている.

筆 18 図 線毛運動停止淔後の沺胞

第19図第18图に゙示しだ細胞に5\%醌酸を加えた数秒 後の变化で，線毛さ形が不規則となり，胞体及び核縮 小し，原北萁內並びに核內は緷いてゅろ不明暸になる が、核脂さ不規則に厚くなり黑く解明に認められる。

第 20 図 籍 19 図に帄続いて胞体士急染に些化し，原形 賀に薄く霞んだようになりるの構造は全く不明となる。

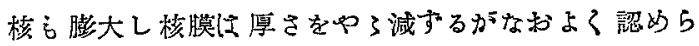
れる。

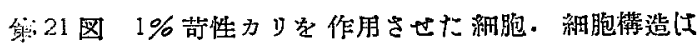
治えど消失して不明となるが，特殊顆粒のみがとのまろ 垡る。

擱筆するに当り恩㸝片桐主一教授の御指導並びに 佂䂭閆に対し深謝玟します。また御教示を仰いだ解 剖学教室水平敏知教授に感謝㮹します。

（原稿到着＝昭和 33.7.29日） 